\title{
Developing Nomograms for Identifying Allergic Rhinitis Among Chronic Rhinitis: A Real-world Study
}

Keywords:

Posted Date: February 23rd, 2021

DOl: https://doi.org/10.21203/rs.3.rs-48535/v2

License: (c) (i) This work is licensed under a Creative Commons Attribution 4.0 International License.

Read Full License 


\section{Abstract}

The authors have requested that this preprint be removed from Research Square. 